\title{
A Way Too Far: Analyzing the Dilemma of Turkey to Joining the European Union
}

\author{
Abdullah Yuhannan \\ Middle East Institute, Sakarya University, Sakarya, Turkey \\ Email: tonpanansatun@gmail.com
}

How to cite this paper: Yuhannan, A. (2017) A Way Too Far: Analyzing the Dilemma of Turkey to Joining the European Union. Open Journal of Social Sciences, 5, 165-185.

https://doi.org/10.4236/jss.2017.57011

Received: May 31, 2017

Accepted: July 11, 2017

Published: July 14, 2017

Copyright $\odot 2017$ by author and Scientific Research Publishing Inc. This work is licensed under the Creative Commons Attribution International License (CC BY 4.0).

http://creativecommons.org/licenses/by/4.0/ (c) (i) Open Access

\begin{abstract}
Turkey has made significant progress step towards EU integration. However, reaching for a full member remains unsuccessful, due to many self-limited dimensions and various arguments against Turkey. The purposes of this study were as follows: 1) to analyze the dilemma of Turkey's EU accession process; and 2) to develop an understanding of the arguments against Turkey membership. This study focuses on various empirical studies and use of both the qualitative and quantitative methods. The result showed that various arguments surrounding Turkey's projected accession revolve around a series of issues, ranging from the current debates in Turkey's politics and democratic breakdowns, human rights abuses, Turkey's demographic structure, economic dilemma and also, historical and cultural issues. These reasons are all the significant causes that have still been problematic issues for Turkey, to be a complete candidate in $\mathrm{EU}$ in nowadays.
\end{abstract}

\section{Keywords}

Turkey's EU Membership, Demographics of Turkey, Turkish Economy, Human Rights, Christian Club

\section{Introduction}

As the result of Ottoman Empire's collapse following World War I, Turkey has established new modern era and adapted the country to "Europeanize" and became a NATO's member. In1959, Turkey applied for "associate membership." During the 1990s, Turkey proceeds with a closer integration with the European Union by the establishment of the Customs Union in 1995 and in 2005 Turkey's official status is as a candidate for full membership. For Turkish's accession to the European Union, Turkey must reform the country under membership conditions and meet the legal requirements and treaty. However, Turkey's application for EU accession probably is never comfortable because of many current 
members of EU countries that remain against Turkey's membership and European public view; the result shows that half of European member countries were against Turkey to join the EU and support countries are predominantly based on "right-based" post-national arguments while oppositions are mainly connected with 'identity-related' arguments.

However, there are several reasons to "Against" Turkish EU membership whether it is a matter of geographic of Turkey, political debate that Turkey is not a mature European-style democracy and the political party still look Islamists party. Violating the declaration of human rights issues are continued. Furthermore, economic issue is that even Turkey's economy had grown but Turkish's GDP remains less than half the EU average and Turkey's wealth is unequally; There is also the matter of history, culture, and religion of Turkey that Turkey's historic and cultural roots lay in Central Asia and the Middle East more than to shared experiences with Europeans and culture of Muslim in Turkey is quite different from Christian Europe. In addition, many scholars have criticized that EU is not accepting Tukey as a member because "The EU is a Christian club"? As a result of the Muslim population that was rapidly increased in Europe and issues of terrorism, consequences, the flow and increasing Islamophobia and anti-Islam trend in Europe.

\section{Purpose of the Study}

1) The overall objective of this study is to analyze the dilemma of Turkey's negotiations with the European Union for accession to the European Union, future challenges and prospects for the EU, if Turkey has successfully to join European Union.

2) The object of this research study is to develop an understanding of the arguments against Turkey's EU membership and why does the EU keep Turkey out?

3) The purpose of this paper is to describe and analyze further information about Turkey and EU enlargement problems and prospects for membership.

4) The proposed research I submit herewith will be useful for those who are interested to studying in the European Union and Turkey relations matters, and people who need to know more how close is Turkey to joining the EU.

\section{Research Questions}

1) What dilemma on Turkish membership to the European Union and how is the current status of Turkey in the process of EU accession negotiations?

2) What are the arguments support and against Turkey's accession to the EU?

3) Should Turkey be given membership in the European Union? And what are the future challenges facing the EU and prospect, if Turkey became a full membership?

\section{A Brief History of Turkey's Accession to the European Union}

After the Ottoman Empire's downfall following World War I, Turkish has the 
revolution led by Mustafa Kemal for Turkish war independence. Mustafa Kemal's fundamental principle was the complete independence of the country. $\mathrm{He}$ became the first President of Republic Turkey, began wide-ranging reformations in economic perspectives, building the new Republics with legislative, judicial, social, cultural, and economic structures system.

(M. Sükrü Hanioglu, 2017). He brings many radical reforms with the goal of transforming the religion-based from the Ottoman system into the new era as the Western country. Each change signified as an arrow in this specification. This defining ideology of the Republic of Turkey is considered to as the "Six Arrows," or called Kemalist ideology. [1]

During World War II, Turkey still playing a role as the neutral state until in 1945, Turkey was joined the Allies side and make the country was part of the Marshall Plan and the OEEC in 1948 because of Turkey need to get the guarantee the security of the US and for rebuilding European Economies. During 1949, Turkey became a member of the Council of Europe. Turkey joined NATO's member in 1952, for against Soviet expansion into Mediterranean area. In1959, Turkey applied for "associate membership" in the European Economic Community. During this time the country's tumultuous transition to multiparty democracy was interrupted by military coups d'état in 1960, 1971, and 1980, as well as a military memorandum in 1997 [2]. Since 1963, Turkey has signed the "Ankara Agreement" so, this agreement creating an association between Turkey and the European Economic Community (ECC). The Ankara Agreement also sought to integrate Turkey into a customs union with the EEC while acknowledging the final goal of membership [3]. Also, following year of this agreement attempted to integrate Turkey into a customs union with EEC while acknowledging the final goal membership. In the 1970s there was a further "Additional Protocol" established more cooperation between Turkey and the ECC. This also set a timetable for the abolition of tariffs and quotas on goods traded between Turkey and the EEC (Council of Europe, 2006).

On 1987 Turkey submitted its application for formal membership into ECC and Turkey's application to accede to European Economic Community was made on April 1987. Turkey presented its request for official membership with the EEC. Then the European Commission responded by confirming Ankara's eventual membership in December 1989. However, during this time also by deferring the matter to more favorable times, citing political situation and Turkey's economic, as well Turkey has poor relations with neighbor's country like Greece and the conflict issues with Cyprus. Until the 1990s, Turkey proceeds with a closer integration with European Union (EU) by the establishment of Customs Union in 1995. The next significant step in EU-Turkish relations came with the December 2002 Copenhagen European Council. According to it, the EU would open negotiation between EU and Turkey without delay, and there was an initiation of EU negotiations with Turkey. The European Commission recommended that the negotiations should begin in 2005.

The issue of Cyprus also continues to be a significant obstacle to negotiations, 
in 2009 the Republic of Cyprus blocked 6 chapter of Turkish accession negotiations, including the fundamental right, Judiciary, energy, culture, and education. Arguing that Turkey needs first to normalize relationships with Cyprus, but no chapter Turkey can open other than the difficulty and public procurement that most candidate countries open at the end of accession as all the other chapter are blocked. In November 2013, "Chapter on Regional Policy \& Coordination of Structural Instruments" is fully opened. The EU became to launches the Visa Liberalization Dialogue with Turkey during December 2013 and is more step for Turkey to closer with the EU membership. At the beginning, on January 2014, France officially withdraws its veto over Chapter 11 "Agriculture \& Rural Development". This chapter ever was blocked by both Cyprus and France, so it cannot be unfrozen until Cyprus withdraws its veto. In November 2015, during the EU-Turkey Summit the EU welcomes Turkey's commitment to accelerate the fulfillment of the Visa Roadmap benchmarks in return for halting the flow of Syrian refugees from Turkey to Greece (European Commission, 2016).

During December 2015, France officially removes its veto over 14 December 2015-Chapter on "Economic \& Monetary Policy" unfrozen and opened. Turkey accession to the EU is always against by great member country as France. Nevertheless, in March 2016 France officially removes its veto over Chapter 17 "Economic \& Monetary Policy", Chapter 33 "Financial \& Budgetary Provisions" and in June 2016, Chapter on "Financial \& Budgetary Provisions" also is opened. The obstacle for Turkey to access to EU remain even Turkey can pass the almost chapter rule to accession to be the member of the EU. Suspend negotiations with Turkey remain as a human rights issues in Turkey about the Kurdish minority group in Eastern part of Turkey and some problem with Cyprus remaining including the rule of law concerns and the transparent in Democracy of AKP government led by President Recep Tayyip Erdogan.

\section{Membership Conditions for Turkish's Accession to the European Union}

The EU operates comprehensively and manages approval procedure with Turkey that for ensuring Turkey is eligible demonstrated to be able to be part of full membership, by:

\subsection{Legal Requirements}

The EU is base a rule of law. This means that every activities and action taken by the EU is founded on treaties. A treaty is an agreement between EU member countries to sets out EU objectives, the rule for EU institutions and how decisions are made between EU and member countries. Turkey tries to carry on and following with all step of membership condition for accession to EU's member. On April 1987, Turkey made a formal application to become a full member of the EU with the procedure set out by treaties.

\section{Article 237: Treaty of Rome}

"Any European state may apply to become a member of the Community". [4] 
By doing this, Turkey was a natural candidate for EU full member and Turkey came closer with EU and hopes that closer relation between Turkey and EU should be encouraged soon.

\section{Article F: Maastricht Treaty}

"Member states shall have systems of government [...] founded on the principles of democracy". [5]

Following this treaty, The Union shall respect the national identities of its member states, whose principle of democracy are the base of the government of member states, in the case of Turkey, according to this treaty Turkey tries to make a transparent of government and clear status of democracy in Turkey. Member need to respect fundamental right and protection human right and make a freedom in their country, according to this rule Turkey's policy was some changed for toward and respect right of people, especially, Kurdish minority in Eastern part of Turkey and was established many necessary things to attain its objective of EU and carry through its policies.

\subsection{The "Copenhagen Criteria"}

The Copenhagen criteria are the rules that define whether a country is eligible to join the EU. On 12 December 2012, European council state was claimed to Turkey that need to apply for EU's member that "The EU would open negotiations with Turkey without delay" if Turkey able to fulfills the Copenhagen criteria. Thus, in 1993 European Council establishes three criteria for Turkey and applicant countries that need to be a member of EU:

1) Stable institutions guaranteeing;

2) Functioning market economy and the capacity to cope with competitive pressure and market forces within the Union;

3) Ability to take on the obligations of membership.

These criteria require that if Turkey needs to be a full member state should have a stable institution to preserve democratic governance in their country and has human right with their people, has a capacity in competitive of the market economy and accepts all the obligations of EU. Most of the criteria elements were clarified by the legislation of European Council, the European Parliament, and the European Commission, including the European Court of Human Rights and the European Court of Justice. Nevertheless, there are also sometimes quite conflicting interpretations in current member countries.

\subsection{The accession Process}

Negotiations between candidate country and European Commission is one of the essential accession processes to become EU's member, For Turkey's accession process is in a category of its own-very different to that of other applicant because it is said to be "too big", "too poor" and "too Muslim", although there is no reason why the countryside, its predominantly Muslim religion and economic underdevelopment in certain area, most notably in the impoverished southeast should be stumbling blocks on the road to accession. Moreover, to accede to 
the EU, Turkey must complete negotiations of with EU on 33 of the 35 chapters of the total body of EU law [6]. After that Turkey will have the opportunity and will agree by EU's member to granting Turkey membership to the European Union.

\section{Turkey and the Dilemma of European Union Accession Process}

Turkey's application for EU accession probably is never comfortable because various members of EU countries remain against Turkey's membership to join the EU. There have many opposed reasons whether it is a matter of geographic and demographics debate of Turkey, the economic issue facing, political issues about the lack of democracy and the rule of law, massive human rights violations against Kurds in Eastern part of Turkey. There also has the international political dilemma for Turkey to access to the EU such as regional issues between Turkey - Cyprus, and Greece and including the Armenian Genocide. Also the matter of Turkish religious background and the culture debate that Turkey's historic and cultural roots lay in Central Asia and the Middle East more than to shared experiences with Europeans and culture of Muslim in Turkey quite different from Christian Europe. Also, many scholars have criticized that EU is not accepting Tukey as a member because "The EU is a Christian club"?

\subsection{Geographic and Demographics Debate}

As we have known Turkey is a country that is settled between East and West, the gathering place of more than two continents, Europe and Asia offer Turkey become a great geopolitical country and appealing strategy in the world. However, many member countries from EU's opinion on Turkey are not exactly a European country. Since more than $90 \%$ of Turkey's territory lies in Asia and also under Western eyes the EU does not need to be shared borders with conflict state as neighboring countries of Turkey like Syria, Iran, and Iraq as a migrants issue in the future. Moreover, Turkey is too large for the EU to integrates and with the growing population increasing and changed in demographic from neighbor migrants from conflict state like Iraqi, Afghanistan and last recent from Syrian refugees. The country predicted to reach 95 million by 2050. So, this will be effect on members of the EU in the future.

\subsubsection{Geographical Regions of Turkey}

The geographical layout of Turkey is diverse, due to the location and position of the country are located both of Asia and the European continent. Turkey is surrounded by three seas and country allocated into seven geographical regions including, the Aegean, Eastern Anatolia, Central Anatolia, Southeastern Anatolia, Marmara, Black Sea, and the Mediterranean region. The biggest land area of Turkey is Anatolia, which connects Turkey to Asia. The majority of the Anatolia area is covered by small coastal plains and high plateaus. The east, most of the land is mountainous and connected to major river ways and also close with Middle East part. On the West and East Turkey are separated by Sea of Marmara 
that is connected with Aegean sea through Strait of Dardanelles and similarly with black sea it is connected by Strait of Bosphorus.

The issue on geographic borders of Turkey is one of the arguments against Turkey to be part of the EU that country mainland are not lie in Europe and is rooted in the age-old debate on whether it is possible to build geographic boundaries for Europe, and whether Turkey fits within these frontiers. As from the argument, the cartography is a clear enough single factor: $3 \%$ of the northwestern part of the Turkey, half of Istanbul, and $10 \%$ of the population are technically in the European region, and the other part rest is in Asia. However, it is slightly complicated. Tectonically, Europe and Asia are one continent, and the geographical boundaries we have drawn are rather arbitrary. Most of Turkey is within Asia, though a small fraction of Turkish territory is on the European side of the Hellespont channel. Furthermore, the present capital of Turkey, Ankara, is well within Asia and the country is considered geographically "Asian." Although, the significant part of Turkey located in Asia can be verified with a simple glance at the map.

However, this is only a general debate. In fact, Turkey has been a prominent geopolitical player on the European continent for more than six centuries. Especially, during The Ottoman Empire, at the climax of its power during $16^{\text {th }}-17^{\text {th }}$ century, it crossed three continents, controlling much of Southeastern Europe, North Africa, and Western Asia. The Ottoman Empire contained 29 provinces and many vassal states, some of which were later absorbed into the empire, while others were granted different kinds of autonomy during centuries. The empire also momentarily gained authority over distant overseas lands through declarations of loyalty to the Ottoman Sultan and Caliph. The empire was at the hub of cooperation linking the Eastern and Western worlds for six centuries. With Constantinople as its capital city and significant control of lands around the eastern Mediterranean during the reign of Suleiman the Great (ruled 1520 to 1566), the Ottoman Empire was, in several regards, an Islamic successor to the Eastern Roman (Byzantine) Empire.

At this point, If thinking about the geographical debate to against Turkey to access to the EU member so we should consider based on both logic, history, and geography and need to considered country entirely not just only Turkey in today. Because of before Turkey was founded in 1923, Ottoman Empire owned many parts of Europe for several years, of course, it also owned some areas of the Middle East and even Africa (Figure 1). However, the Ottoman sultans chose to mix their culture mostly with other European cultures, not with Middle Eastern, Asian, or African ones. Furthermore, as the historical reason the border of Ottoman Empire in Europe lie on to the Vienna, Hungary was part of Ottoman Empire, some Italian and Spanish coastal cities were used as naval bases by Ottoman Empire too.

\subsubsection{The Demographics of Turkey}

Nowadays, Turkey recognized as a modern European country and home to a 


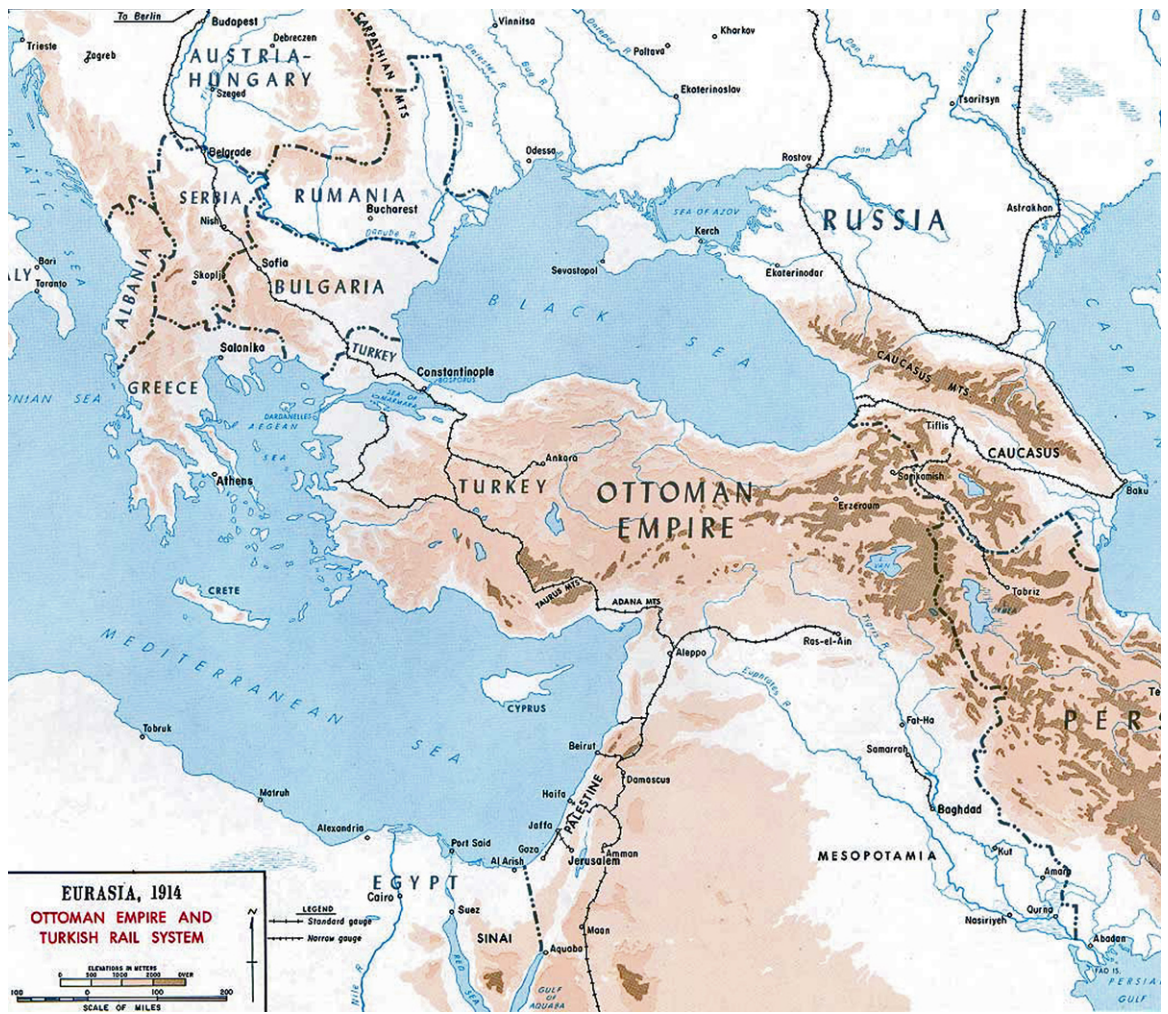

Figure 1. Map of Ottoman Empire in 1914 (Source: emersonkent.com (n.d.).

diversity of cultures country. This is partially due to a huge amount of enlargement they carried out during the middle ages periods. According base on the latest United Nations estimates in March 2017, the current population of Turkey is $80,181,553$ (Worldometers, 2017). One of the demographic issues of Turkey to against to access to the EU is the current immigrant crisis of Syrian refugee that is the neighbors country of Turkey. Migrant crisis makes Europe facing large of the problem. As a result of Syrian refugees, issues make European public view against Turkey and extend Turkey's EU member hold in the process. According to United Nations estimates, Syrian refugee's population in the country was more than over 2.8 million as a beginning of January 2017, that have crossed since 2011 after the start of the Syrian Civil War. As a result of the war, make large of Syrian number escaped to the neighbor country like Turkey. Nowadays, Turkey has now become the world biggest for Syrian refugee country (Burak Kocamis, 2016) and hosted more than 2.8 million, and this will be one of the demographic changing for Turkey in the future if accepted Turkey to be a member and this one of the biggest obstacle for Turkey in demographic debates.

Others demographic argument is from the fear that Turkish immigrants will flood into Western Europe. Today, Germany and the Netherlands, where 2.5 million and 250,000 respectively of the 3 million Turks living in the EU reside, were particularly afraid of immigration. Although many of these fears seem reasonable, they are not completely convincing on a closer look. It is true that Turkey now has a population of more than 70 million inhabitants in Europe, and in contradiction to the biggest country now, Germany, its people is rising at a con- 
siderable rate. By 2020 Turkey would be the highest country with about 15 percent of the entire EU population (Eurostat, 2016). Thus, the concern that Turkey would dominate over Europe.

\subsection{Economic Debate}

Turkey's economy had grown averaged for 2014 around 3.5\%, and it seems much better than most EU nations. Per capital, income has increased six-fold, and the average Turk is now better off than his neighboring countries such as Romanian and Bulgarian counterparts in the EU. However its recent growth, Turkey remains a poor economy. Turkish's GDP remains less than half the EU average. Turkey's wealth is unequally between the wealthy and poor people in their country, its mean if accepted Turkey as a member, poor immigrants from other parts of Turkey will be heading and move to the west. Also, even though Turkey's economic has increased significantly but unemployment is also still rising.

\subsubsection{The Turkish Economy Issues}

One of the concentration issues on Turkey's EU membership is relevant to its economic performance. In fact, in most all document published by the Commission, such concerns are shown mainly in the Turkish economy. That is not unusual; however, the economic factors constitute much of the debate on the accession of a new member if the economic reasoning is taken into account as an initial step for the establishing of the EU and also for further action of EU integration. In this respect, the economic developments that Turkey will achieve throughout the accession process will be perceived positively in the way towards its membership. As stated in the Commission Working Document, those future developments in the economic field will define the nature of the economic impact of Turkey's membership of the EU. In this regard, it is useful to look at the important indicators that could reflect the situation of Turkey about the issues arose on free movement of workers, which were also taken into consideration in previous enlargements. For about the economic performance-income gap, if wee looking to the Gross Domestic Product (GDP) in Turkey contracted 2.70 percent in the third quarter of 2016 over the past quarter. GDP Growth Rate in Turkey averaged 1.07 percent from 1998 until 2016, reaching an all-time high of 5.60 percent in the first quarter of 2002 (Trading Economics, 2017).

Turkey is classified as an emerging market economy. The country is one of the world's largest producers of agricultural products, motor vehicles and other transportation equipment, ships, textiles, construction materials; consumer electronics and home appliances (Trading Economics, 2017). And when we looking to the minimum wages in the EU states compare with Turkey, we can found that in 2008, between EU candidate nations, only Turkey had a national minimum wage, and by 2017 this had risen by 35\% compared with the January 2008 level of EUR 354 [7]. Based on the level of their national gross monthly minimum wages shown in euro terms, the EU Member States related to this data collection may be divided into three various groups. 
All of the EU candidate countries had minimum wages that were similar in group 1, and most of them are Scandinavian and Western European countries, while in group 2 and group 3 are seems difference. While the candidate member minimum wage as Turkey (EUR 479) is the similar quiet minimum of group 2 the EU member countries and is better than some states of current, the EU member in group 1 as their national minimum wages ranged from EUR 235 in Bulgaria to EUR 470 in Estonia (Figure 2). So as this statistic that we can see from the past till now we found that Turkey minimum wage was improved fastest if we compare with other EU candidate member and currently EU member in group Three even Turkish Lira become weak, but the Turkish economy are remain increasing in all part. Consequently, the debate that Turkey ever use to attack Turkey about the minimum wage of Turkey issue that still lower than EU member are should be no longer to against Turkey on this issues.

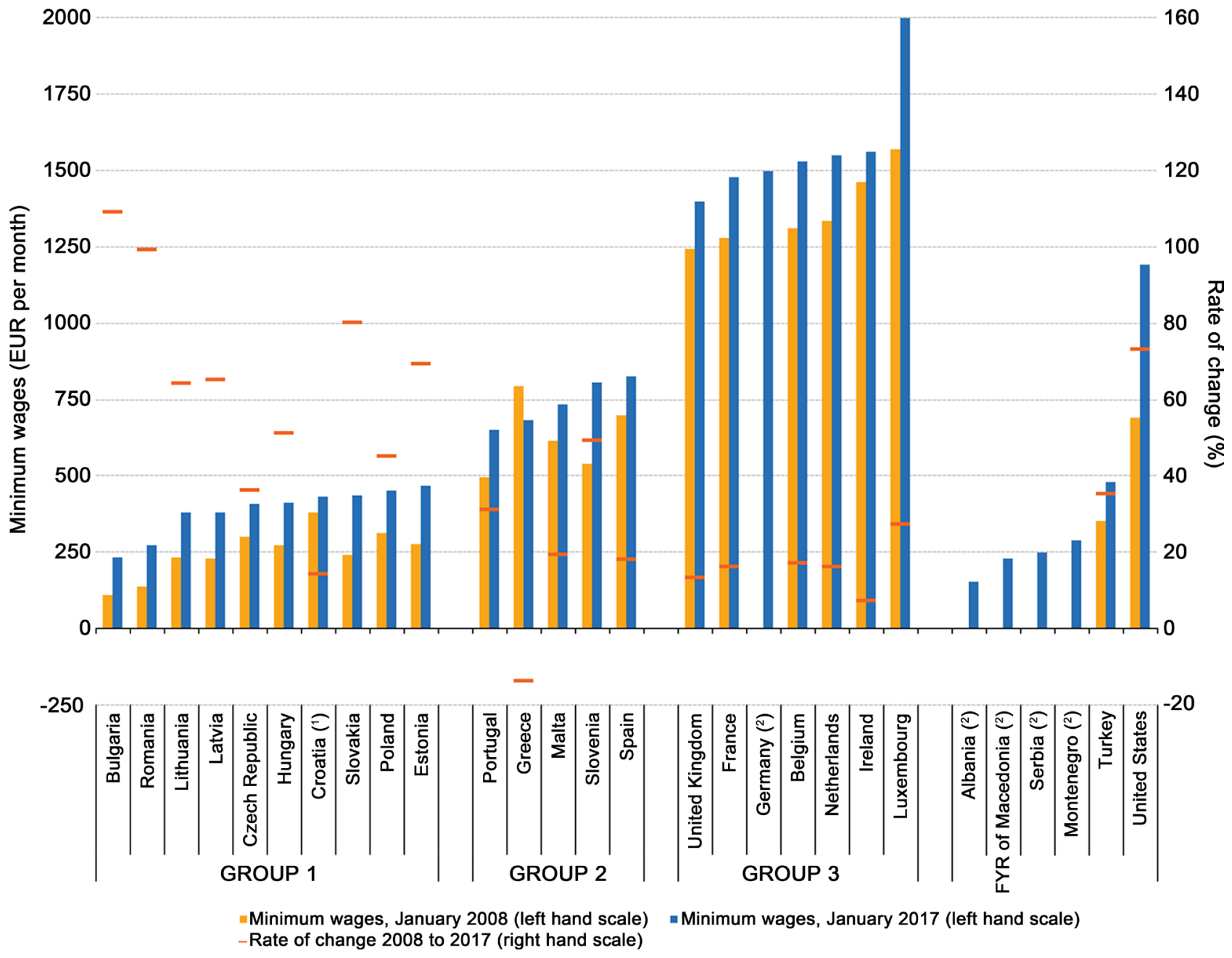

Note: Denmark, Italy, Cyprus, Austria, Finland and Sweden: no national minimum wages.

(') June 2008 instead of January 2008.

${ }^{(2)}$ January 2008 and rate of change: not available.

Source: Eurostat (online data code: earn mw cur)

Figure 2. Turkey and the EU Gross Minimum Monthly Wage updated on January 2017 (Source: Eurostat, 2017). 


\subsubsection{Turkish Unemployment Rates and the Potential Migration Estimates Issues}

The other issues for against Turkey to join the EU is Turkish Unemployment Rates, we can see from the latest increase, the Turkish unemployment has reached a comparable rate to Italy, which is at 11.9 percent in November 2015. Greece, Spain, and Cyprus are the countries which scored a bigger joblessness rate than Turkey. However, even when Turkey unemployment rate compared with the EU average, it is seen that unemployment rates in Turkey are higher, which could strengthen the views of opponents to Turkey's membership concerning the unemployment dilemma. It could also serve as a negative impression of the Member States, in particular on those with low the unemployment rates accompanied by relatively high wages, for the opening of their labor markets to Turkish workers.

Turkey had higher unemployment rates (12.7\%) than the EU averages (8.2\%) in December 2016. However, due to the negative impact of the Economic crisis on labor markets, some EU member both are big and small economic countries also had higher unemployment rates than the EU average such as Greece (23.0\%), Spain (18.2\%), Cyprus (14.1\%), Italy (11.9\%), Croatia (11.3\%), Portugal (10.2\%), France (10\%), Latvia (9.7\%), Finland (8.7\%), and Slovakia (8.6\%) [8]. In this regard, it can be discussed that the relatively weak record Turkey has with concerns to unemployment is not an uncommon case to against Turkey access to the EU anymore, particularly at the time of the economic crisis.

On the one hand, this could be portrayed positively in a sense that even though the unemployment rate in Turkey is well above the average, it is not the only country having this unemployment problem but also many of other EU Member States get this trouble too. On the other hand, this could generate further concerns about Turkey's unemployment dilemma for those nations which similarly have high unemployment in their labor markets same as Turkey. Therefore, accession of Turkey may posture a warning of additional unemployment within the Union, which could mean that more people would explore for a job in the EU labor market. It could even be a more significant concern concerning the youth, whose capacity to migrate is considered to be relatively high.

As a result, it would not be remarkable that Turkey could face with longer transitional periods on free movement of workers if the adverse impact of the crisis on the labor markets of EU members could not be overwhelmed at the time of its accession. However, one should support in mind that permanent protection conditions for free movement of labour are not adequate since the membership of the EU out of a fundamental right appreciated by Turkish nationals is opposed to the spirit of the membership. Moreover, it is false from the side of acceding country that Turkish nationals who would become EU citizens would be denied of one of their primary rights and this, in return, would be facing the principle of equal operation.

On the last argument for Turkey to access the EU in economic debate is about the Potential Migration Estimates, The potential migration from Turkey to the 
EU has also drawn the attention of some scholars, although most of the studies on Turkey's accession to the EU concentrated on purely political and economic dimensions of the accession. However, it should be put in understanding that migration is an essential part of the economic factors of enlargement. Furthermore, the issue of immigration is interrelated with cultural and social conceptualizations of the impact of further the EU accession member. Thus, beyond reflecting the numerical change in the resident and working population in one Member State, migration is a crosscutting phenomenon which could be examined from a wide range of different perspectives (demographic, economic, cultural and social, etc.).

\subsection{Political Debate}

Turkey is one of the perfect and successful Muslim democracy countries in the world. The prospect of EU membership makes Turkey has a good democracy system, good governance and increasing aware of human rights issue that always is ever an obstacle to improving democracy system in Turkey. Moreover, as Turkey is a strong member of NATO ally is also part of super regional power over the Middle East. Nevertheless, there has some debate on Turkish politic that Turkey is not a mature European-style democracy. Turkish political system remains affected by using heavy military force against minority and political parties still look Islamists party. Violating the declaration of the human rights issues continue. A large number of journalists and reporters who published media anti-government side remain arrested by the state, free speech in public was controlled, and the minority rights are unfair, especially, Kurdish issues in Eastern part of Turkey, regional issues with Cyprus and Greece and also the Armenian Genocide most are the debate against Turkey and make the dilemma for Turkey to access the EU member.

\subsubsection{The Rule of Law, Democracy, and Human Rights in Turkey}

The EU is joined in its concern about a lack of Turkish democracy but is clearly divided on how to react and so has been left with some influence. Turkey has largely retreated on the rule of law, local sovereignty, separation of powers, and freedom right of expression. In 2014, EU member countries considered note of social media bans, obstruction of the investigation into corruption accusations, and the narrowing of space to express critical opinions of judges-including a new law on the internet that gave the Telecommunications Directorate the power to block an entrance to websites without a Turkish court mandate. According to the Telegraph report; that after several years of improvements in freedom of expression, there was now "serious backsliding seen over the past two years." The EU criticized current powers that the government gave itself to block internet content, and in the latest year, there have been several situations where new internet laws were used to censor the public [9].

Some EU member states that are supportive of starting new chapters with Turkey are less willing to use the political capital of Turkey, reserving it alter- 
nately for discussions on Eastern Partnership nations. In 2014, the Netherlands lobbied unsuccessfully for Turkey to accept lower amounts from the EU Instrument for Pre-Accession Assistance (IPA) 2014-2020 budget, but the new IPA budget does allocate more money to increasing the potential of rights-focused civil society organizations [9]. As a result of the wrong of political activity and lack of the democracy in Turkish government now, however, the European Parliament has mentioned that Turkey remains one of an essential partner as a NATO member and as a competitor for EU membership.

Although the country's opportunities to advance in the accession process needs the full respect by the Turkish governments to follow all the Copenhagen criteria, the human rights and the rule of law in Turkey must be maintained and including the principles of the European Convention on Human Rights is should fully be respected too. There also has the refuges dilemma of Turkey accession to the EU to consider on the political dimension as the EU negotiates with Turkey over its membership into the Union in an attempt to solve refugee crisis. Brussels has criticized Turkey of significant backsliding on the rule of law, human rights and freedom of expression in a sensitive report that had been held back until after elections (Raziye, 2015). The latest progress report on Turkey's EU candidacy comes after the ruling party co-founded by Recep Tayyip Erdogan, the Turkish president, returned to power in a shock election result. The scathing report, which assesses a country's status as an accession candidate, criticized Ankara's adoption of laws that impacted the rule of law, freedom of expression and freedom of assembly which "ran against European standards (Raziye, 2015).

\subsubsection{The Kurdish Question and Turkey's EU Membership}

As pointed out previously about Turkey's accession to the EU and Kurdish dilemma for Turkey, to understand this issue we need to know the background to the Turkish discussion on minority rights. It is highly necessary to include the EU in the overall background to understanding key factors in Turkey's domestic discussion on minority rights, especially on Kurdish issues. With these requirements at hand as a reference, it can be established which of the minority rights Turkey is quiet not living up to The EU Commission establishes that Turkey's access to minority rights has continued unchanged since the previous releases.

According to the Turkish authorities, minorities in Turkey consist exclusively of non-Muslim societies, this is despite the fact, the EU Commission declares, that there are other communities which could qualify as minorities. Moreover, the Commission explains Turkey's restrictions regarding the rights of minorities to the UN Covenant on Civil and Political Rights (ICCPR) and the UN Covenant on Economic, Social and Cultural Rights (ICESCR) [10]. The Commission acknowledges that there has been a greater understanding towards the use of the Kurdish language during the past few years, though there remain significant restrictions. For example, there are still restrictions on the use of languages other than Turkish by political parties. Moreover, the Commission regards to a European Commission against Racism and Intolerance (ECRI) report, which supports the Turkish authorities to reconsider Article 42 of the Constitution, which 
forbids the teaching of any language other than Turkish as a mother tongue in public schools.

The same report also highlights the need to take comprehensive measures proposed at reducing barriers to access to public services of the country for those who do not speak and using the Turkish language. Moreover, the Commission observes that the teaching of Kurdish encountered a serious difficulty as in August 2005 when all existing programs in Kurdish were closed down by the government. The decision to close down the programs was caused by various factors, particularly since it is required to pay for them, but also due to additional factors such as lack of financial support, restrictions regarding the curriculum, selection of teachers, timetables, and attendees. The Commission also observes there is some improvement concerning social and cultural rights. In the EU's Progress Report on Turkey's Accession (William Chislett, 2006) stated that Two local TV channels in Diyarbakir and one radio channel in Şanliurfa were granted permission to broadcast in Kurdish. However, the broadcasting is limited in many ways. Except for films and music programs, time limitations apply, and all broadcasts (except songs) must be subtitled or translated into Turkish. Furthermore, educational programs teaching the Kurdish language are not permitted. The Turkish Public Television (TRT) has remained broadcasting in five languages including Kurdish. Nevertheless, the duration and scope of TRT's national broadcasts are still very restricted.

In sum, the Commission maintains that Turkey made little progress on supporting cultural diversity and the regard for and protection of minorities by international standards. It has also been concluded that the minority idea is problematic for some reasons. First, there is no consent to the representation of minority in international conventions. Second, many Kurds dislike the idea of being identified minority. Third, it is the State that chooses what cultural groups they want to give minority status and official Turkey appeals to the Lausanne Treaty. Furthermore, the tension between adaptation and identity is necessary. Some Kurds and other minorities have adopted a Turkish identity over time. While voluntary adaptation is fine, forced adaptation is certainly a dilemma. Whereas some of the ideas put progressive in the discussion can easily be applied to the multicultural frame, others do not fit in. The theoretical debate on multiculturalism is largely a Western debate where the most significant matter in dispute is whether cultural minorities are best preserved by individual groupspecific rights or not. The multiculturalists discuss that group rights are needed, whereas the liberals think that these organizations are better defended by liberal equality.

\subsubsection{The Issue of Cyprus in the EU Accession of Turkey}

The Cyprus issues are the cause of separate Greek, and Turkish communities represent one of the most complicated issues of the European Union's sixth enlargement round, with the future of Turkey's EU accession discussions connecting on the successful resolution of the dilemma. So the background of Cyprus is from after the Cyprus obtained independence from Britain in 1960. Three years 
later, the inter-communal struggle broke out among the Mediterranean island's Greek and Turkish communities, which finally led to a Greek-sponsored effort to seize power in 1974 and a military invasion by Turkey. Greek Cypriot refugees escaped to the south as Turkey seized the island's northern part, although Turkish Cypriots directed to the north. In 1983, the Turkish-held northern part of the island declared itself the 'Turkish Republic of Northern Cyprus' (TRNC) [11].

Afterward, a series of debates among the EU-25 states, the Council on 3 October 2005 determined to open accession talks with Turkey. Following the negotiating frame for the country, Ankara's progress in its agreement talks will be held, among others, by its continued support for efforts to reach a broad agreement on the Cyprus [11]. The problem within the UN framework and in line with the principles on which the Union is established, including steps to contribute to an agreeing climate for a complete settlement, and progress in the normalization of two-sided relations between Turkey and all EU member states, containing the Republic of Cyprus. The Cypus issue between Greece and Turkey remain going on, during April 2009, an opinion poll conducted by the Cyprus Broadcasting Corporation $(\mathrm{CyBC})$ showed that the majority of Greek Cypriots supported separation." [12]

In 2017, mainstream publications in the south of Cyprus stated since the two sides are so satisfied and comfortable with the status quo, negotiating the formalization of separation rather than appealing reunification is the reasonable thing [13]. An international committee of legal experts suggested the "creation of a Constitutional Convention under European Union auspices and by the 1960 Cyprus Constitution to bring together the parties directly concerned to approach a settlement in conformity with the Fundamental Attitude." [14] Critical peace critics suggest that a resolution to the Cyprus conflict can only be achieved by including society on a broad base, as political elites began to exploit the dispute as a source of power and resources [15]. Moreover, also in an official White House statement on June 8, 2016, by US Vice President Joe Biden and Turkish Prime Minister Binali Yildirim reaffirmed strong support for "An adjustment on the agreement by using the reunifies the island as a bizonal or bicommunal federation." [15]

\subsubsection{The Armenian Genocide and EU-Turkey Relation}

A report from the International Association of Genocide Scholars, published in the International Herald Tribune (France) on 23 September 2005 (Harry, 2005), reaffirmed the well-established evidence of Armenian genocide. The report stressed that it is not just Armenians who are declaring the Armenian Genocide, but it is the overwhelming view of scholars who study genocide: hundreds of independent scholars, who have no connections with governments, and whose work crosses many countries and societies. It replied unequivocally:

"We believe that it is unmistakably in the interest of the Turkish people and their future as satisfied and equal participants in international, democratic discourse to acknowledge the obligation of a previous government for the genocide 
of the Armenian people." [16]

As the German government and German people have done in the case of the destruction. Denying the claims of those historians who deny the genocide, the report had hard words to Turkey. It said, "We would also remark that scholars who advise your government and who are connected in other ways with your country controlled institutions are not unbiased". Such so-called "scholars" work to serve the agenda of historical and moral obfuscation when they advise you and the Turkish government on how to deny the Armenian Genocide. With the undeniable evidence in the German and Austrian archives of WWI (allies of Turkey) endorsing the genocide committed against Armenians, it is time for Turkey to stop its monotonous rejection and through cover the way not only for a cleaner EU-bound slate but also for recovered relations with Armenia and security in the Caucasus territory.

Recognition of the Armenian Genocide is admittedly an ethical necessary, but it also helps increase state relations and carries with it the weight of geopolitical and democratic concerns. Just like the recent spate of declarations from many EU Parliaments, and following the two Resolutions of $15^{\text {th }}$ September by the US House International Relations Committee (H.Res.316 and H.Con.Res.195), it is high time to stop the abrupt demonstrations of a displaced ideological nationalism that spell rejection. Turkey must not only constitute reforms and submit them to the EU as proof of progress, but it should also perform them on the ground. Unless, criminal justice and judicial systems would continue steeped in decades of nationalist ideology, strengthened by an authoritarian constitution, and could reveal any reformist government's best purposes.

There is no point in evading responsibilities towards History: better to acknowledge, to mend and to be reconciled. Germany fully realized this following 1945, and that is what made possible its involvement, with equal rights, in European building. [17] Indeed, a significant challenge was put forward by Armenian Foreign Minister Vartan Oskanian at an International Conference on the 90th Anniversary of the Armenian Genocide in Yerevan on 21st April. Called Ultimate Crime, Ultimate Challenge, his closing address included the subsequent set of questions: Armenians were one of the biggest minorities of the Ottoman Empire [18]. Where did they go? Is it feasible that all our grandmothers and grandfathers created fake stories? Where are the descendants of the Armenians who built the hundreds of churches and monasteries whose still stand in Turkey [19]?

Is US Ambassador Henry Morgenthau's report of the crimes that he observed a lie? Moreover, why was a military court gathered at the end of WWI, and why did it find Ottoman Turkish leaders wrong of ordering the mass murder of Armenians? How does one explain the thousands and thousands of pages of the official records of a dozen countries reporting the plans to abolish the Armenian population of the Ottoman Empire? If it was not genocide and they were just 'wartime exiles' of so-called rebel Armenian populations near the eastern border with the Russian Empire, as Turkish apologists sometimes declare, why were the 
places of Armenians in the Western cities robbed and burned? Moreover, why were the Armenians of the seaside towns of Smyrna and Constantinople dismissed?

In a study entitled Eight Stages of Genocide by Gregory H Stanton, he wrote that "denial is the eighth stage that always follows a genocide" [20]. How the perpetrators refuse that they performed any crimes, and often examine what happened to the victims. Once Turkey believes its responsibility to recognize the genocide, we could witness the start of a fresh dawn for Armenians and Turks equal, and perhaps also a reduction of the large gap that separates our EU political organizations from our day-to-day realities. There also has an article entitled Turkey's Memory Lapse: Armenian Genocide Plagues Ankara 90 Years On in the German Spiegel International (Online) [21]. On $25^{\text {th }}$ April, Bernhard $Z$ and wrote: Faced with more and more Armenia resolves in European parliaments, opinion is developing among some that Ankara's position on the Armenian problem could eventually threaten its prospects for EU membership. Though there is no official claim that Ankara recognizes the murder of the Armenians as "genocide".

\subsection{Religious Background and the Culture Debate}

Turkey has been fully a part of Europe's history since the Ottomans era in the $14^{\text {th }}$ Century, whose rich cultural heritage and traditions are unique, EU membership is also an opportunity for resolving the Kurdish problem as well as relationships with Cyprus and Armenia. Moreover, as Turkey in contemporary shows as a prosperous Muslim democracy, this model would send a clear sign that Europe is open to the Islamic world. EU membership would be representative of Turkey's success as a secular Islamic state and a model for others Muslim countries.

However, the definitions that position Europe and Islam as opposite and opposing entities practiced in political discussions in preventing Turkey's accession to EU membership. However, "Europe" and "Islam" are only meaningful terms within a particular context, where they used for a particular purpose. For politicians opposing Turkey's EU membership, there is a clash between Islam and Europe. However, the different definitions of "Europe" show that this opposition founded by privileging a historical and cultural Europe based on Christian tradition. As from investigating half a century of Turkish Muslim immigrant participation in Europe [22] shows a variety of interplays between Europe and Islam. Islamic groups such as the Nur movement aim to contribute to the moral and spiritual life of Europe through their idea of civil Islam, and Islamic political groups such as Milli Görüş convince the European public and consequently reformulate their personal Islamic idea. Milli Görüş is in the process of redefining political Islam in response to various state policies. Young leaders need greater adaptation to Europe, which has become their home. Additionally, in Europe, there also has many Turkish Islamic organization movements to driven Islam ideology and demand to expand the thought of Muslim in Europe. 
Is the European Union a "Christian club"?

However, many Western scholars had to criticize Turkey's historical and cultural roots lay in Central Asia and the Middle East more than to shared experiences with Europeans together, from the cultural legacy of Renaissance and Enlightenment, Turkey's cultural traditions are fundamentally different from that of Christian Europe. Turkey's actual interaction with Europe has always been as an outside invader. Also, many of people, especially the scholars from Turkey believe that EU is not accepting Tukey as member easily because of "EU is the Christian club."

A great many people think Europe is a Christian club? Moreover, many people agreed with this statement especially Turkish's scholars because of many member countries of EU tries not to let into the EU is a member. Moreover, this argument situated by the fact that Europe as a region of Christian. So that, the Turkish membership will make the number of Muslim in Europe will increase in the future and may eventually affect the Christian community in Europe. Especially today, Europe full of a variety of races, nationalities, skin color and religious diversity. In every year, human wave from all around the World trying to enter the European Union member states for to seek good opportunities and to build a new life in western countries that economic and standard of life better than their country and others part of the world. Among the diversity group in Europe is Muslim population that was rapid increased and Islam had become a fast religion in Europe. The growth of Islam in Europe has led to growing acceptance of Hijab, Fasting during the month of Ramadan (holy month of Islam) and other spiritual practice of Muslim and also these are becoming significant events in European society.

For these reasons, will the EU accept Turkey which is a Muslim nation as a full member will affect in the future of Europe? Furthermore, EU must review and rethink in many matters about policy towards Muslim in the future if they accept Turkey as a member. Especially, Stability and security dimension that its remains one of the most significant matters from Muslim terrorist over the world and it is highly necessary for EU member countries to bring their attention to this issues. Particularly, Chalie Hebdo attack on 7 January 2015 that its make shock our World then Paris attacks in November 2015 and ISIS took responsibility for the attacks and hailed them as miracles.

The terrorist problem in Europe later follow with the Brussels bombings in March 2016 and Normandy church attack in July 2016 and also the Nice truck attack in July 2016 on Bastille Day, France's national day, it was later claimed that had been "radicalized" by ISIS and Muslim. Moreover, during March 2017, the attack outside the Houses of Parliament in London is the latest in a series of terrorist atrocities [23]. The 2017 Westminster Attack was a panic attack carried out by Muslim United Kingdom resident Khalid Masood, who drove an automobile into pedestrians and fatally wounded a police officer at the Palace of Westminster in London, England [23]. Followers and member on several ISIS social media celebrated with this successful attack, with many connecting it to 
punishment for British airstrikes in Syria and Iraq and ISIS also run Twitter account declared responsibility for the assault. Consequences, the flow and increasing Islamophobia and anti-Islam trend in western countries and make European's perceptions of Islam have turned increasingly negative in recent years. For this reason, Islamophobia existed in premise before the terrorist of September 11, 2001, in America but it increased in frequency and notoriety during the past decade. For all these reasons bring Muslim left behind the violence, against, hatred or bigotry towards, or fear of the religion of Islam or Muslims. Practicing Muslims face a wide variety of challenges. Even Muslim did not feel entirely safe in daily life.

\section{Conclusion}

Turkey has made great progress step towards EU integration. However, reaching for full member remains unsuccessful, due to many self-limited dimensions and various arguments against Turkey by the members. This study focuses on various empirical studies and use of both the qualitative and quantitative methods, mentions in particular on primary and secondary sources, media analysis, document surveys, and research articles. The result showed that various arguments surrounding Turkey's projected accession revolve around a series of issues, ranging from the current debates in Turkey's politics and democratic breakdowns, human rights abuses, Turkey's demographic structure, economic dilemma and also, historical and cultural matter. Regarding the geographic debate, there is an argument that Turkey is not exactly a European country because more than $90 \%$ of Turkey's territory lies in Asia. The country located close with conflict state as neighboring countries of Turkey like Syria, Iran, and Iraq; the EU does not need to be shared borders with these countries; Moreover, the growing population increasing predicted, it will effect on members of the EU in the future.

While in other reasons to against Turkey's EU member like Political debate, even, Turkey is one of the perfect and successful Muslim democracy countries in the world. The prospect of EU membership makes Turkey has a good democracy system. Nevertheless, Turkey is not a mature European-style democracy; Turkish political system remains affected by using heavy military force against minority and political parties still look Islamists party, violating the declaration of the human rights issues continue. A large number of journalists who published media antigovernment side remain arrested by the government; free speech in public was controlled, and the minority rights are unfair; especially, Kurdish issues in Eastern part of Turkey and the Cyprus problem are continue.

The other strong reason is about the economic debate, Turkey's economy had grown every year, and it seems much better than most EU nations. Per capital, income has increased. However its recent growth, Turkey remains a weak economy. Turkish's GDP remains less than half the EU average. Turkey's wealth is unequally between the wealthy and poor people in their country; it means if accepted Turkey as a member, poor immigrants from other parts of Turkey will 
be heading and move to the west. Also, even though Turkey's economic has increased significantly but unemployment is also still rising. In the last debate it is about the History, Culture, and Religion of Turkish people. Turkey has been fully a part of Europe's history since the Ottomans era in the $14^{\text {th }}$ Century, whose rich cultural heritage and traditions are unique, EU membership is also an opportunity for solving the Kurdish issue as well as relations with Cyprus and Armenia. Moreover, as Turkey in contemporary shows as a prosperous Muslim democracy, this model would send a clear sign that Europe is open to the Islamic society. Nevertheless, many Western scholars had to criticize Turkey's historical and cultural roots lay in Central Asia and the Middle East more than to share experiences with Europeans together, from the cultural legacy of Renaissance and Enlightenment, Turkey's cultural traditions are fundamentally different from that of Christian Europe. Turkey's actual interaction with Europe has always been as an outside invader.

In addition, many of people, especially the scholars from Turkey believe that EU is not accepting Tukey as member easily because of "EU is the Christian club." A several of people agreed with this statement because of many member countries of EU try to against Turkey to access to the EU member. This argument established by the fact that Europe as a region of the Christian country. Therefore, the Turkish membership will be shaped the number of Muslim in Europe will increase in the future and finally will affect the Christian community in Europe. For these reasons, it's highly crucial issue for EU member countries to bring their attention to this problem and must concern how to make a policy towards Muslim in the future if they accept Turkey as a member. Particularly, stability and security dimension that its remains one of the most significant matters in the EU state.

\section{References}

[1] Taha Parla and Andrew Davison (2004) Corporatist Ideology in Kemalist Turkey: Progress Or Order? Syracuse University Press, Syracuse.

[2] Hale, W.M. (1994) Turkish Politics and the Military. 1st Edition, Routledge, Oxford, $161,215,246$

[3] Embassy of the Republic of Turkey (2007) Turkey and EU. Washington, DC.

[4] European Commission (n.d.) Treaty of Rome. Viewed 16 December 2016. https://ec.europa.eu/romania/sites/romania/files/tratatul_de_la_roma.pdf

[5] European Commission (n.d.) Maastricht Treaty. Viewed 18 December 2016. http://www.cvce.eu/content/publication/1997/10/13/5a6bfc79-757f-4d53-9379-ad23 cc2cc911/publishable_en.pdf

[6] Golder (n.d.) A Conversation with Meryem Tekol. Viewed 22 February 2017. http://www.golder.com/id/en/modules.php?name=Newsletters\&op=viewarticle\&sp _id=163\&page_id=1100\&article_id=518

[7] Statistics (2017) Minimum Wage Statistics. Viewed 22 March 2017. http://ec.europa.eu/eurostat/statistics-explained/index.php/Minimum_wage_statist

[8] Statista (2017) EU: Unemployment Rate 2017 by Country. Viewed 23 March 2017. https://www.statista.com/statistics/268830/unemployment-rate-in-eu-countries/ 
[9] Akkoc, R. (2015) EU Attacks Turkey's Backsliding on Rule of Law, Human Rights and Freedom of Expression. Telegraph Media Group.

[10] Amnesty International USA (2013) Malaysia: Prevention of Crime Act Undermines Fundamental Fair Trial Rights and Due Process. Viewed 28 March 2017. http://www.refworld.org/docid/52710b2c4.html

[11] Euractiv (2007) Turkey Accession and Cyprus. Viewed 2 April 2017. http://www.euractiv.com/section/enlargement/linksdossier/turkey-accession-and-cy

[12] Cyprus Mail (2017) Why the Majority Need Partition. Viewed 5 April 2017. http://cyprus-mail.com/2017/02/05/majority-want-partition/

[13] Cyprus Mail (2017) Our View: Time for a Dramatic Final Act in the Cyprob Saga. Viewed 5 April 2017. http://cyprus-mail.com/2017/03/26/view-time-dramatic-final-act-cyprob-saga/

[14] Committee for a European Solution in Cyprus. A Principled Basis for a Just and Lasting Cyprus Settlement in the Light of International and European Law. https://ifestos.edu.gr/a-principled-basis-for-a-just-and-lasting-cyprus-settlement-in -the-light-of-international-and-european-law-by-the-international-expert-panel-co nvened-by-the-committee-for-a-european-solut/

[15] Vogel, B. and Richmond, O. (2013) Enabling Civil Society in Conflict Resolution. Cultures of Governance and Conflict Resolution in Europe and India.

[16] The International Association of Genocide Scholars (2007) The House Resolution Recognizing and Commemorating the Armenian Genocide. Viewed 9 April 2017. http://www.genocidescholars.org/sites/default/files/document\%09\%5Bcurrent-page \%3A1\%5D/documents/US\%20Congress_\%20Armenian\%20Resolution.pdf

[17] Hagopian, H. (2005) EU-Turkey \& the Armenian Genocide. Viewed 28 March 2017.

http://www.newropeans-magazine.org/en/2005/10/24/eu-turkey-the-armenian-gen ocide-part-i-3/

[18] Ara, S.A. (2005) Armenia's Policy on Genocide and Turkey's EU Membership. Minister of Foreign Affairs of Armenia.

[19] Hagopian, H. (2005) EU-Turkey \& the Armenian Genocide. Viewed 28 March 2017. http://www.crag.org.uk/articles/article24.html

[20] Stanton, G.H. (1998) The 8 Stages of Genocide. First Working Paper, Yale Program in Genocide Studies, Yale University, New Haven.

[21] Zand, B. (2005) Turkey's Memory Lapse: Armenian Genocide Plagues Ankara 90 Years. Viewed 2 January 2017.

http://rotter.net/cgibin/forum/dcboard.cgi?az=show_thread\&forum=gil\&om=5494 \&omm $=35 \&$ viewmode $=$ threaded

[22] Yükleyen, A. (2009) Compatibility of "Islam" and "Europe": Turkey's EU Accession. Insight Turkey, 11, 113-115.

[23] Cheezburger (2017) Westminster Attack. Viewed 6 April 2017. http://knowyourmeme.com/memes/events/2017-westminster-attack 
Submit or recommend next manuscript to SCIRP and we will provide best service for you:

Accepting pre-submission inquiries through Email, Facebook, LinkedIn, Twitter, etc. A wide selection of journals (inclusive of 9 subjects, more than 200 journals)

Providing 24-hour high-quality service

User-friendly online submission system

Fair and swift peer-review system

Efficient typesetting and proofreading procedure

Display of the result of downloads and visits, as well as the number of cited articles Maximum dissemination of your research work

Submit your manuscript at: http://papersubmission.scirp.org/

Or contact jss@scirp.org 